\title{
Development of STEM Animation Learning Media with Feedback to Facilitate Students' Critical Thinking Ability on Global Warming Materials
}

\author{
Fitria Lafifa ${ }^{1,}$ Parno Parno $^{1 *}$,Erti Hamimi ${ }^{1,}$ A M. Setiawan ${ }^{1}$ \\ ${ }^{1}$ Science Education, Universitas Negeri Malang \\ "Corresponding author.Email: parno.fmipa@um.ac.id
}

\begin{abstract}
Critical thinking skills are needed to face the $21^{\text {st }}$ century. PISA 2018 data shows that students' critical thinking skills are still low. The Earth is experiencing an increase in temperature so it requires a solution to overcome it. STEM animation learning media with feedback can increase student reality and involvement and make it easier for students to understand concepts by linking STEM elements. The application of STEM learning media animation with feedback is still rarely used to build capabilities of critical thinking. The purpose of this study was to develop STEM animation learning media with feedback to facilitate students' critical thinking skills on appropriate global warming materials. This study uses Research and Development and ADDIE model's 5 stages, namely Analysis, Design, Development, Implementation, and Evaluation. The instrument used is a media validation questionnaire, material, and readability. The results of the average percentage of test material were $95,1 \%$ and media $94,3 \%$ with very decent criteria. The percentage of students' readability test has an average value of $81 \%$ with a very decent category. So, this media can facilitate students to think critically on global warming material. For future researchers, it is recommended to use the product as a medium of learning in the classroom.
\end{abstract}

Keywords: Animation learning media, STEM, STEM-feedback animation, Critical thinking, and Global warming.

\section{INTRODUCTION}

The increase in temperature that is currently happening is one of the impacts of global warming [1]. Global warming can occur because the earth's temperature has increased so that it can lead to climate change [2]. The increase in temperature of the earth can be seen through the sea surface temperature in 2018 ranged between $25^{\circ} \mathrm{C}-26^{\circ} \mathrm{C}$, in 2019 ranged between $26^{\circ} \mathrm{C}-27^{\circ} \mathrm{C}$, the year 2020 ranging from $30^{\circ} \mathrm{C}-31^{\circ} \mathrm{C}$. On May 23,2020 , it became the highest sea surface temperature value, reaching $30,8^{\circ} \mathrm{C}$ [3]. The results of the study in 2020 showed that the SPL reached a higher value than in 2019. The sea surface temperature is a benchmark to see the impact of climate change due to global warming. These data provide an overview of the existence of climate change in the future [4].

Understanding global warming material is important because students need to analyze the causes and impacts of global warming so that they can provide solutions to overcome these problems [5]. The problem that occurs in global warming material is that students still often experience misconceptions about global warming material [6]. Students still think that the material on global warming is difficult, this is indicated by the data that students find it difficult to answer questions in the form of global warming problems of $81.25 \%$ [7]. Science material is material that is still abstract so that students still have difficulty understanding it and make students feel bored so that it can cause misconceptions that affect students' critical thinking skills [8].

Several studies have been conducted to develop students' abilities on global warming material. The research in question is the use of discovery learning models to train students' scientific literacy skills [9], implementation of spot capturing learning to improve science process skills [10], development of science magazines to increase student interest in learning [5], Student worksheet 7E learning cycle model to improve critical thinking skills [11], the application of the beach ball type class discussion model to improve student learning outcomes [12], global warming worksheets with SETS vision to improve critical thinking skills [13], blended learning to 
increase the level of critical thinking skills [14], skills students' critical thinking in the implementation of the discovery learning model [15]. From these studies, it can be concluded that critical thinking skills have been studied more, but there are still few who have researched the media. Thus, it is necessary to increase critical thinking skills using media on global warming material.

Critical thinking skills are needed in everyday life to face life's challenges so that students can face all the problems in everyday life [16]. The survey results from PISA in 2018 showed that the critical thinking ability of students in Indonesia in science material was low with a rank of 71 out of 79 countries with a score of 396 which decreased compared to 2015 which was 403 [17]. The low ability of students' critical thinking on global warming material is shown by pre-test data on class VII E Junior High School 20 Surabaya [18]. The low critical thinking ability of students is due to students being less active in developing their knowledge independently [19].

Several studies have been conducted to overcome the low critical thinking skills of students on global warming material. The research in question is the application method with a scientific approach [18], the application of discovery learning models [20], electronic teaching materials [21], constructivism-oriented SETS-oriented worksheets [13], learning media in the form of interactive multimedia [22], and instructional video media. based on local wisdom [23]. These studies have weaknesses, including the lack of updates that can make students analyze and think critically so that they can produce products, and there is no reciprocal relationship or feedback by students in using the media as a form of communication so that active learning occurs. It appears that learning media solutions on global warming materials are still rarely used. Also, the learning media developed was only in the form of static audio-visual. From this research, no research has been found that develops animation media that applies STEM with feedback to facilitate students' critical thinking skills on global warming material.

Learning media serves to help students understand the concept by presenting the material concretely so that students become more active [24]. Learning media on global warming material is important because global warming is related to natural phenomena so it will be very difficult to present it in learning [7]. Animation can explain abstract concepts into concrete in the form of moving images so that it is easier for students to understand concepts [25, 26]. Thus, animated learning media can present a non-static visualization of the material phenomenon of global warming.

STEM learning is an approach by combines science, technology, engineering, and mathematics in learning so that it can help students gain knowledge independently and skillfully solve problems in real life [27]. Learning STEM animation will make material that is still abstract more concrete because learning STEM animation directly relates the material to everyday life [28]. STEM animation learning media can make it easier for students to understand the concept [29]. Thus, STEM animation learning media can make students analyze and think critically about the global warming phenomenon through the manufacture of Engineering products.

Feedback by students is a form of active communication in media learning. Thus, feedback is an important thing that must exist in the media because communication will occur through feedback [30]. Learning on the media will be more meaningful and active because of the feedback [31]. One form of feedback is by giving information warnings in the form of wrong and right answers by giving opinions [32].

The emergence of critical thinking skills is influenced by the provision of feedback [33]. Feedback and critical thinking are interrelated entities because feedback in the form of evaluation is needed in forming a concept of critical thinking [34]. Feedback in learning media can improve critical thinking skills and train students to solve problems independently [35]. STEM animation learning media can improve concept understanding better through critical thinking [28]. Students' critical thinking skills can be increased by using a STEM approach accompanied by feedback [36].

Based on this description, the development of STEM animation learning media with feedback is still rarely done. So it is necessary to develop STEM animation learning media with feedback that aims to facilitate students' critical thinking skills so that learning becomes active and students can determine solutions to solving a problem. This study aims to develop a STEM animation learning media with feedback to facilitate students' critical thinking skills on valid and appropriate global warming material

\section{RESEARCH OF METHODS}

This type of research uses Research \& Development $(\mathrm{RnD})$ which aims to produce a product [37]. This study uses the ADDIE model because this model has revision steps at each stage so that it is up-to-date and relevant [38]. The product result is in the form of STEM animation learning media with feedback to facilitate students' critical thinking skills on global warming material in the form of a smartphone application. The research design using the ADDIE model consists of 5 stages, namely analysis, design, development, implementation, and evaluation. Table 1 showed the details of the research stages with the results obtained.

Table 1. Table of Details of Research Stages

\begin{tabular}{|l|l|}
\hline \multicolumn{1}{|c|}{ Stages } & \multicolumn{1}{|c|}{ Results } \\
\hline Analysis & $\begin{array}{l}\text { Earth temperature change data and } \\
\text { literature study problems }\end{array}$ \\
\hline
\end{tabular}




\begin{tabular}{|l|l|}
\hline \multicolumn{1}{|c|}{ Stages } & \multicolumn{1}{c|}{ Results } \\
\hline Design & $\begin{array}{l}\text { Storyboard, Indicator of achievement of } \\
\text { basic competencies, critical thinking } \\
\text { question instrument, and questionnaire } \\
\text { assessment instrument }\end{array}$ \\
\hline Development & $\begin{array}{l}\text { Media, validation results, and revision } \\
\text { results }\end{array}$ \\
\hline Evaluation & $\begin{array}{l}\text { The revised product is based on the } \\
\text { responses and suggestions of students } \\
\text { and validators }\end{array}$ \\
\hline
\end{tabular}

The Analysis stage is an analytical activity that aims to find the right solution to the problem and determine the characteristics of students [39]. The activity carried out by the researcher is to analyze the problems that occur in the global warming material and students. Then collect data on changes in the earth's temperature for several years and conduct literature studies.

At the Design stage, it is carried out to determine specific competencies, methods, learning strategies, teaching materials, and media [39]. The activities carried out storyboards containing concepts, materials, and views. Making Indicators of achievement of basic competencies based on basic competencies and critical thinking indicators, questionnaire assessment instruments consisting of material validation sheets, media, and student readability tests.

At the Development stage by making teaching materials and programs that will be used in learning activities [39]. Activities carried out by researchers are developing media, conducting product validation tests, and revising products based on suggestions from validators. Media and material validation questionnaires were filled out by lecturers and teachers in charge of science subjects. The questionnaire produces quantitative and qualitative data. Quantitative data in the form of the Likert scale and Guttman scale. Qualitative data in the form of suggestions and responses from validators and students of Junior High School 23 Malang.

At the Implementation stage, it is done by applying the design of the learning program to the learning activities [39]. The activity carried out by the researcher was to test the product to junior high school students who had taken global warming material by distributing a readability test questionnaire. The questionnaire produces quantitative and qualitative data. Quantitative data in the form of a Likert scale while qualitative in the form of student responses.

At the Evaluation stage, the learning program evaluation stage [39]. The activity carried out by the researcher was to revise the product according to student responses. The final result of the research is a product that is ready to use.

Data analysis consists of 2 types, namely quantitative and descriptive. Quantitative data were obtained from the results of material and media validation questionnaires filled out by lecturers and science teachers at Junior High School 23 Malang and readability questionnaires by students at Junior High School 23 Malang.

Qualitative data in the form of suggestions and responses from validators and students. Readability, material, and media questionnaires used a 4-level Likert scale, namely very good, good, poor, and not good. The correctness of the concept uses the Guttman scale in the form of a statement with a yes answer for a score of 1 and no for a score of 0 . Then add up the overall score on each questionnaire and calculate it with the percentage score formula. The percentage score can be formulated as follows.

$\mathrm{P}=\frac{\sum R}{N} \times 100 \%$

Description :

\section{$\mathrm{P}=$ Percentage score}

$\mathrm{R}=$ Total score of answers given by each respondent

$\mathrm{N}=$ Total ideal score

Furthermore, after calculating the average percentage score, it is continued by concluding the data criteria $[40,41$, 42]. Table 2 showed the results of the average percentage score.

Table 2. Table of Eligibility Criteria for Questionnaire Data

\begin{tabular}{|c|c|l|l|}
\hline No & $\begin{array}{c}\text { Score } \\
(\%)\end{array}$ & \multicolumn{1}{|c|}{ Qualification } & \multicolumn{1}{|c|}{ Information } \\
\hline 1 & $81-100$ & Very good & $\begin{array}{l}\text { Very feasible/very } \\
\text { valid }\end{array}$ \\
\hline 2 & $61-80$ & Well & Eligible / valid \\
\hline 3 & $41-60$ & Pretty good & $\begin{array}{l}\text { Inappropriate/ less } \\
\text { valid }\end{array}$ \\
\hline 4 & $21-40$ & Not good & $\begin{array}{l}\text { Inappropriate / } \\
\text { invalid }\end{array}$ \\
\hline 5 & $<20$ & Not very good & $\begin{array}{l}\text { Very } \\
\text { inappropriate/very } \\
\text { invalid }\end{array}$ \\
\hline
\end{tabular}

Qualitative data in the form of suggestions from validators and students are taken into consideration in developing or improving products.

\section{RESULTS AND DISCUSSION}

The product that has been developed is a learning media in the form of an application that can be used on an android smartphone accompanied by a user guide for the application. This learning application is presented in the form of animation with integrated STEM which is equipped with practice questions on critical thinking on the topic of global warming. It is intended that students have critical thinking skills that can be applied in everyday life to overcome 
challenges and problems in everyday life [16]. In addition, the application is presented in the form of animation which aims to make the material presented to students more visible so that the material can be understood by students well and there are no misconceptions [43]. The developed application displays several menus, namely Basic Competence and GPA, Instructions for Use, Material and Practice Questions, About, Quit Button. Figure 1 and Figure 2 showed the initial appearance of the application and the homepage.

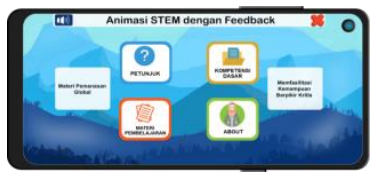

Figure 1 Image of Application Start Page.

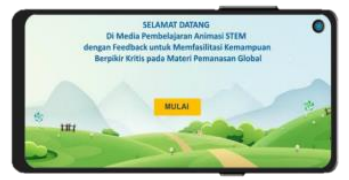

Figure 2 Image of Application Home Page.

Figure 1 showed the initial display when opening the application. The initial screen contains a welcome greeting, a title, and a start button that is equipped with an audio background. The start button is used to start the application so that you can learn about global warming.

Figure 2 showed what the home page looks like. The home page displays a title with several menus and application buttons. On the menu, the material is presented in the form of images, animations, and texts accompanied by audio narration effects that will facilitate students' understanding in mastering global warming material that has been integrated with STEM. The use of this STEM approach can serve to improve students' critical thinking skills by combining Science, Technology, Engineering, and Mathematics [44].

The Basic competence menu contains basic competencies and basic competency achievement indicators to be achieved in learning. Basic competency achievement indicators are prepared based on critical thinking indicators for global warming material. The user guide menu contains an explanation of how to use the application. The About menu contains application developer biodata as owner information for copyright. There are several buttons, namely the music icon and across. The music icon functions to turn off and turn on the background music in the application. The cross button is a Quit menu that serves to exit the learning application. In the material menu, there are several submenus, namely the greenhouse effect, global warming, the impact of global warming, and efforts to overcome global warming.

The greenhouse effect submenu displays the concept of the greenhouse effect material and the process of its occurrence in the form of animation and audio. Then, an animation of the experimental process of the greenhouse effect is shown, accompanied by conclusions from the experiment and exercises on critical thinking and discussion. The element of Science can be seen from the experimental animation of the process of the greenhouse effect which makes students more scientific in understanding it materially and related to everyday life besides that students can observe experiments and analyze the results of observations. This is by the element of Science in STEM, namely Science in STEM is the use of knowledge and skills of the scientific process which aims to understand natural phenomena in everyday life [45]. Science applies its learning activities not only to knowledge but also to skills that will make students think critically by being able to analyze material and events in everyday life [46]. At the end of the experiment, there is also a conclusion and discussion where according to the procedures in Science there is a stage of concluding the experimental results based on the information obtained and then adjusting it with provisional assumptions [47]. Critical thinking skills are presented in materials and questions with Evaluation indicators, students can interpret the problems given by properly describing the relationship between relevant variables and Analysis indicators, with the existence of a phenomenon students can provide appropriate arguments and based on analysis that is by the concept [48].

In the submenu of global warming and the causes of global warming shown the concept of global warming in the form of animation and there are exercises critical thinking and discussion. The element of Technology is contained in the animated display that causes global warming, namely tools related to the principle of global warming used by humans. This is by the Technology component in STEM which consists of all organized human systems, knowledge, processes, and devices that can be used [49]. Critical thinking skills are presented in materials and questions with Inference indicators, data, graphs, or images are presented and students can make conclusions correctly based on data, graphs, or images presented based on the correct concept [48].

In the submenu, the impact of global warming is shown the problems caused by global warming which is detrimental to humans. The material is presented in the form of animation and there are exercises on critical thinking and discussion. Critical thinking skills are presented in questions with Interpretation indicators, students can interpret the problems given by describing the relationship between relevant variables appropriately [48].

In the submenu of efforts to overcome global warming, solutions to overcome and prevent global warming are shown that can be applied in everyday life. An animation of making solar panels is displayed simply and at the end of each material, there is an exercise in critical thinking and discussion. Elements of Engineering is a technique for 
designing and using technology solutions that are applied to overcome global warming which is shown in the animation of making simple solar panels with the results in the form of miniatures. This is by the Engineering component in the STEM element which is more directed to how to operate, design, or assemble based on the previously developed science and technology [45].

Elements of Mathematics is a mathematical calculation in solving global warming problems, namely calculating the electrical power needed to make solar panels. Based on the components of STEM elements, Mathematics is more about analyzing by showing evidence and the existence of problemsolving to interpret a solution from the data obtained and the results of calculations [45]. Critical thinking skills are presented in materials and questions with self-regulation indicators, students can explain the causes of events that can occur based on the knowledge they know and then relate them to the material. Explanation indicator, students can make statements and provide explanations based on the correct concept [48].

In each material and at the end of the sub material, feedback is given to facilitate students' critical thinking skills [34]. Feedback is presented in the form of practice questions by providing false and correct information accompanied by a discussion [50]. Giving true or false information is useful to warn students that the concepts they understand are still wrong so that discussions are displayed and students can relearn the material through discussion and then answer the questions again with the correct answers. So, with feedback, it will form a concept of critical thinking skills [34].

This application media has been tested for the feasibility of the material, the media, and the readability test. The product feasibility test consists of media and material validation which is assessed by one lecturer of the Science Education Study Program, Universitas Negeri Malang, and one science teacher at Junior High School 23 Malang. Obtaining the average percentage of media assessments and material is presented in Tables 3 and Table 4.

Table 3. Table of Average Percentage of Media Rating Scores

\begin{tabular}{|c|l|c|c|}
\hline No & \multicolumn{1}{|c|}{ Rated aspect } & $\begin{array}{c}\text { Average } \\
\text { Score } \\
(\%)\end{array}$ & $\begin{array}{c}\text { Assessment } \\
\text { criteria }\end{array}$ \\
\hline 1 & $\begin{array}{l}\text { Use of words or } \\
\text { language }\end{array}$ & 93.8 & Very Feasible \\
\hline 2 & Design and Graphics & 93.1 & Very Feasible \\
\hline 3 & Presentation Aspect & 94.6 & Very Feasible \\
\hline 4 & Application Benefits & 95.6 & Very Feasible \\
\hline
\end{tabular}

STEM animation media resulted in the acquisition of a percentage of the feasibility of the material with an average of $95,1 \%$ with a very valid category [51]. The results of the media feasibility test resulted in an average eligibility
Table 4. Table of Average Percentage of Material Assessment Scores

\begin{tabular}{|c|l|c|c|}
\hline No & \multicolumn{1}{|c|}{ Rated aspect } & $\begin{array}{c}\text { Average } \\
\text { Score (\%) }\end{array}$ & $\begin{array}{c}\text { Assessment } \\
\text { criteria }\end{array}$ \\
\hline 1 & $\begin{array}{l}\text { The suitability of the } \\
\text { material with KD }\end{array}$ & 91.7 & Very Valid \\
\hline 2 & Material Accuracy & 91.7 & Very Valid \\
\hline 3 & Material Update & 95.9 & Very Valid \\
\hline 4 & Learning Presentation & 96.4 & Very Valid \\
\hline 5 & Concept Truth & 100 & Very Valid \\
\hline \multicolumn{2}{|c|}{ Average } & 95.1 & Very Valid \\
\hline
\end{tabular}

percentage of $94,3 \%$ with very feasible criteria [51]. In addition, qualitative data were also obtained in the form of suggestions from the validator, namely the media can be used on laptops. The improvements are presented in Figures 3 and Figure 4.

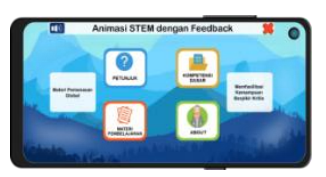

Figure 3 Smartphones display images.

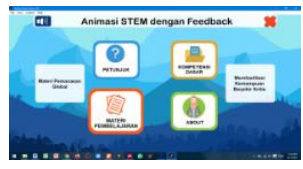

Figure 4 Laptop Display Picture.

Figure 3 shows the appearance of the application on a smartphone. Figure 4 shows the appearance of the application on a revised laptop.

In addition, the readability test of the application that has been carried out produces quantitative and qualitative data. Quantitative and qualitative data were obtained from 30 class IX students of Junior High School 23 Malang who filled out a questionnaire.

From the results of the readability test the percentage of eligibility obtained is $81 \%$ with very feasible criteria. Qualitative data obtained in the form of responses, namely the application is good, can be used easily, students feel happy using this application. In addition, students are easier to understand the material, the application can motivate students to learn independently, and is very fun.

Based on the results of the feasibility and legibility test results, it is shown that media is very feasible to function for application media that can facilitate students in critical thinking independently. This is by the research that animation applications can make students more active in learning and 
learning objectives can be achieved [26], by integrating STEM aspects can improve students' critical thinking skills [52]. STEM animation learning can improve students' conceptual understanding skills better and can relate the material to everyday life [28], the feedback makes learning more active and meaningful so that communication occurs [30] and can bring up critical thinking skills [34].

The advantages of this study are the appearance of the application is attractive, can be a medium for student selflearning, can be operated offline, can be used on android smartphones and laptops, the explanation of the material with text, images, audio, and animation. Each question has feedback in the form of a discussion of each question and information on correct and incorrect answers, practice questions based on indicators of critical thinking skills. The drawback of this research is that it is limited to Basic Competencies 3.9, which is global warming material. Cannot be operated other than Android smartphones.

\section{CONCLUSION}

Based on the results of the feasibility test products can be inferred that the media is very feasible to use the average value of the media $94,3 \%$ and $95.1 \%$ material. From the results of the readability test, the developed media has an average readability test percentage of $81 \%$ with a very feasible. Therefore, media can be used to facilitate the critical thinking skills of junior high school students on global warming material. The recommendation for future research is to use the product in the classroom as a learning medium.

\section{AUTHORS' CONTRIBUTIONS}

All authors conceived and designed this study. All authors contributed to the process of revising the manuscript, and in the end, all authors have approved the final version of this manuscript.

\section{ACKNOWLEDGMENTS}

The author would like to thank various parties who have helped this research, especially the supervisors and validators, and students of Junior High School 23 Malang.

\section{REFERENCES}

[1] M. W. Solihin, S. H. B. Prastowo, and Supeno, "Pengaruh Model Pembelajaran Inquiri Terbimbing Terhadap Kemampuan Berpikir Kritis Siswa SMA," 7(3) (2018) 299-306.

[2] A. S. Mulyani, Antisipasi Terjadinya Pemanasan Global Dengan Deteksi Dini Suhu Permukaan Air Menggunakan Data Satelit Agnes Sri Mulyani 1, EJournal CENTECH 2020, 2(1) (2021) 22-29.

[3] A. Azizah and H. Wibisana, Analisa Temporal Sebaran Suhu Permukaan Laut Tahun 2018 Hingga 2020 Dengan Data Citra Terra Modis, J. Kelaut. Indones. J. Mar. Sci. Technol., 13(3) (2020) 196-205.
[4] L. Cheng, Upper Ocean Temperatures Hit Record High in 2020, Adv. Atmos. Sci., 38(4) (2021) 523-530.

[5] S. Asfuriyah and M. Nuswowati, Pengembangan Majalah Sains Berbasis Contextual Learning Pada Tema Pemanasan Global Untuk Meningkatkan Minat Belajar Siswa, Unnes Sci. Educ. J., 4(1) (2015) 739-746.

[6] N. Gungordu, A. Yalcin-Celik, and Z. Kilic, Students' Misconceptions about the Ozone Layer and the Effect of Internet-Based Media on It, Int. Electron. J. Environ. Educ., 7(1) (2017) 1-16.

[7] I. K. N. P. Guterres, S. Sudarti, M. M, and P. D. A. Putra, Pengembangan Media Pembelajaran Ular Tangga Berbasis Android Pada Pokok Bahasan Gejala Pemanasan Global Untuk Pembelajaran Fisika Di Sma, J. Pembelajaran Fis., 7(1) (2018) 54.

[8] L. Rifqiyana, Masrukan, and Susilo. BE, Analisis Kemampuan Berpikir Kritis Siswa Kelas Viii Dengan Pembelajaran Model 4K Ditinjau Dari Gaya Kognitif Siswa, Unnes J. Math. Educ., 5(1) (2016) 40-46.

[9] Yaumi, Wisanti, and S. Admoko, Penerapan Perangkat Model Discovery Learning Pada Materi Pemanasan Global Untuk Melatihkan Kemampuan Literasi Sains Siswa Smp Kelas Vii Yaumi Mahasiswa Program Studi Pendidikan Sains FMIPA UNESA, E-Journal Pensa, 5(1) (2017) 38-45.

[10] K. Septaria, B. A. Dewanti, and M. Habibbulloh, Implementasi Metode Pembelajaran Spot Capturing Pada Materi Pemanasan Global untuk Meningkatkan Keterampilan Proses Sains, Prism. Sains J. Pengkaj. Ilmu dan Pembelajaran Mat. dan IPA IKIP Mataram, 7(1) (2019) 27.

[11] L. Mariya and A. Suyatna, Lembar Kegiatan Siswa Model Learning Cycle 7E Materi Pemanasan Global Untuk Meningkatkan Keterampilan Berpikir Kritis Siswa Snf2015-Ii-81 Snf2015-Ii-82, Pros. Semin. Nas. Fis., IV, 2015, pp. 81-86.

[12] S. Z. Rohmah and B. Jatmiko, Penerapan Pembelajaran dengan Model Diskusi Kelas Tipe Beach Ball untuk Meningkatkan Hasil Belajar Siswa pada Materi Pemanasan Global Kelas XI SMA Berbasis Kurikulum 2013, 4(3), 2015, pp. 101-106.

[13] S. Harnani and A. Suyatna, Lks Pemanasan Global Bervisi Sets Berorientasi Kontruktivistik Untuk Meningkatkan Kemampuan Berpikir Kritis, SNF, IV, 2015, pp. 179-184.

[14] R. Fariska and Erman, Blended Learning Untuk Meningkatkan Level Kemampuan Berpikir Kritis, Pensa J. Pendidik. Sains, 5(2) (2017) 60-66.

[15] A. Warda and E. Sudibyo, Keterampilan Berpikir Kritis Siswa Dalam Implementasi Model Discovery Learning Pada Sub Materi Pemanasan Global, E-Journal Pensal Pensa, 6(2) (2018) 238-242. 
[16] L. Nuryanti, S. Zubaidah, and M. Diantoro, Analisis Kemampuan Berpikir Kritis Siswa SMP, J. Pendidik. Teor. Penelitian, dan Pengemb., 3(2) (2018) 155-158.

[17] A. Schleicher, PISA 2018, 2019.

[18] N. Setiorini and T. Nurita, Implementasi Pendekatan Saintifik Untuk Mealtih Keterampilan Berpikir Kritis Siswa Kelas VII Pada Materi Pemanasan Global, EJurnal:Pendidikan Sains, 2(58) (2018) 227-249.

[19] N. Dewi and R. Riandi, Analisis Kemampuan Berpikir Kompleks Siswa Melalui Pembelajaran Berbasis Masalah Berbantuan Mind Mapping, Edusains, 8(1) (2016) 98-107.

[20] N. Haryanti, A. T. Widodo, and Y. Arfiani, Penerapan Model Discovery Learning pada Materi Pemanasan Global untuk Meningkatkan Keterampilan Berpikir Kritis Peserta Didik, J. Edukasi Mat. dan Sains, 7(2) (2019) 55.

[21] W. Suwatra, Pengembangan Bahan Ajar Elektronik Pemanasan Global Untuk Menumbuhkan Keterampilan Berpikir Kritis Siswa Sma (Tesis), Universitas Lampung, 2018.

[22] B. Susanto, Pengembangan Multimedia Interaktif Pemanasan Global Dengan Pendekatan Saintifik Untuk Peningkatan Keterampilan Berpikir Kritis Siswa Kelas XI, Universitas Lampung, 2016.

[23] J. D. E. Rahayu, Pengembangan Media Video Pembelajaran Berbasis Kearifan Lokal Pada Materi Lingkungan Untuk Meningkatkan Kemampuan Berpikir Kritis Siswa Di Smp, Universitas Jember, 2018.

[24] C. Riyana, Komponen-Komponen Pembelajaran, in Komponen-Komponen Pembelajaran, Online: Online, 2011, pp. 1-63.

[25] A. Johari, S. Hasan, and M. Rakhman, Penerapan Media Video Dan Animasi Pada Materi Memvakum Dan Mengisi Refrigeran Terhadap Hasil Belajar Siswa, J. Mech. Eng. Educ., 1(1) (2014) 8.

[26] E. Siswanah, Penggunaan Media Animasi Dalam Mahasiswa Tadris Matematika Iain, J. Phenom., 3(2) (2013) 5-17.

[27] D. A. B. Lestari, B. Astuti, and T. Darsono, Implementasi LKS Dengan Pendekatan STEM (Science, Technology, Engineering, And Mathematics) Untuk Meningkatkan Kemampuan Berpikir Kritis Siswa, J. Pendidik. Fis. dan Teknol., 4(2) (2018) 202.

[28] I. S. Utami, R. F. Septiyanto, F. C. Wibowo, and A. Suryana, Pengembangan STEM-A (Science, Technology, Engineering, Mathematic and Animation) Berbasis Kearifan Lokal dalam Pembelajaran Fisika, J. Ilm. Pendidik. Fis. Al-Biruni, 6(1) (2017) 67.

[29] K. Sukiyasa and Sukoco, Pengaruh Media Animasi Terhadap Hasil Belajar Effect Animation Media on
Student' S Learning, J. Pendidik. Vokasi, 3(1) (2013) $126-137$.

[30] T. Nurseto, Membuat Media Pembelajaran yang Menarik, J. Ekon. dan Pendidik., 8(1) (2011) 19-35.

[31] L. D. Utami, The Development Of Media Chart In Learning Digestive Human System On Science Subjects For Fiveth Grade Students Of Sdn 1 Mojoroto In Academic Year 2016 /, Simki Pedagog., 1(6) (2017) 27.

[32] R. Ana, Kartono, and Masrukan, Pengaruh Corrective Feedback Dalam Pembelajaran Auditory Intellectually Repetition (AIR) pada Pencapaian Kemampuan Representasi Matematis Siswa, Prism. Pros. Semin. Nas. Math., 2, 2019, pp. 10-15.

[33] S. A. K. Narumi, Penerapan Fast Feedback Dalam Pembelajaran Discovery Pada Pencapaian Kemampuan Berpikir Kritis Ditinjau Dari Adversity Quotient," J. Prism. (Prosiding Semin. Nas. Mat., vol. 4, 2021, pp. 406-415.

[34] K. A. Ghurafa and V. D. Sugiarto, Modul Training CIMSA Indonesia Critical Thinking \& Giving Appropriate Feedback. Online: CIMSA, 2020.

[35] E. R. Winarti, B. Waluya, and Rochmad, Meningkatkan Kemampuan Berpikir Kritis Melalui Problem Based Learning Dengan Peer Feedback Activity, J. Elektron. Pembelajaran Mat., 5(2) (2018) 197-207.

[36] Anggi Hary Pasadi, Pengembangan Lembar Kerja Peserta Didik Berbasis STEM (Science, Technology, Engineering, Mathematics) Dan Kearifan Lokal Untuk Meningkatkan Kemampuan Berpikir Kritis Peserta Didik Kelas IV SD, J. Pendidik. dasar, 7(1) (2019) 7478.

[37] Sugiyono, Metode Penelitian Pendidikan, 2018.

[38] H. Guswika, Suhadi, and S. E. Indriwati, Pengembangan Media Penyuluhan Berupa Buku Pintar Tumbuhan Obat, J. Pendidik. Teor. Penelitian, dan Pengemb., 2(12) (2017) 1585-1589.

[39] B. Pribadi, Desain dan Pengembangan Program Pelatihan Berbasis Kompetensi Implementasi Model ADDIE, Kencana, 2011.

[40] R. Likert, A Technique for the Measurement of Attitudes, 140th ed., Archives Of Psychology, 1932.

[41] Sugiyono, Metode Penelitian Pendidikan, 22nd ed., Alfabeta, 2015.

[42] Riduwan, Pengantar Statistika Sosial, Alfabeta, 2012.

[43] W. R. Widjayanti, T. Masfingatin, and R. K. Setyansah, Media Pembelajaran Interaktif Berbasis Animasi Pada Materi Statistika Untuk Siswa Kelas 7 Smp, J. Pendidik. Mat., 13(1) (2018) 101-112. 
[44] A. Satriani, Meningkatkan Kemampuan Berpikir Kritis Siswa Dalam Pembelajaran Kimia Dengan Mengintegrasikan Pendekatan Stem Dalam Pembelajaran Berbasis Masalah," Pros. Semin. Nas. Pendidik. IPA 2017, 1(1) (2017) 207-213.

[45] J. Siswanto, Keefektifan Pembelajaran Fisika dengan Pendekatan STEM untuk Meningkatkan Kreativitas Mahasiswa, J. Penelit. Pembelajaran Fis., 9(2) (2018) 133-137.

[46] R. Z. P. Angin, Penerapan STEM Pada Pembelajaran IPA Materi Bioteknologi, Pros. Semin. Nas. V 2019, 2020, pp. 300-307.

[47] E. M. Reeve, STEM Education is Here To Stay, ITEEA, 2015.

[48] H. Fitriani, M. Asy'ari, S. Zubaidah, and S. Mahanal, Exploring the prospective teachers' critical thinking and critical analysis skills, J. Pendidik. IPA Indones., 8(3) (2019) 379-390.
[49] S. Bahrum, N. Wahid, and N. Ibrahim, Integration of STEM Education in Malaysia and Why to STEAM," Int. J. Acad. Res. Bus. Soc. Sci., 7(6) (2017) 645-654.

[50] A. Ashoori Tootkaboni and M. Khatib, The Efficacy of Various Kinds of Error Feedback for Improvement in the Writing Accuracy of Iranian EFL Learners, Bellaterra J. Teach. Learn. Lang. Lit., 7(3) (2014) 30.

[51] A. Purnamasari and Rochmawati, Pengembangan Alat Evaluasi Pembelajaran Berbasis Teknologi Informasi dan Komunikasi dengan Wondershare Quiz Creator Materi Sistem Penilaian Persediaan, J. Pendidik., 3(1) (2015) 1-10.

[52] N. R. Wahyuaji and Suparman, Deskripsi Kebutuhan Media Pembelajaran E-Learning Berpendekatan STEM untuk Mengembangkan Kemampuan Berfikir Kritis dan Kreatif Siswa SMA Kelas XI, Semin. Nas. Pendidik. Mat. Ahmad Dahlan, 2018, pp. 194-199. 